\section{Commentary: Use of hepatitis C virus viremic donors should be the standard of care}

\author{
Marcelo Cypel, MD, a,b and Ann Woolley, MD ${ }^{\mathrm{c}}$
}

We read with great interest the manuscript "Fishing in the thoracic organ donor pool: what next if the catch of the day got infected with hepatitis C virus?" by Raemdonck and colleagues. ${ }^{1}$ They describe the current status of transplanting organs from hepatitis $\mathrm{C}$ virus (HCV) viremic donors to uninfected recipients amidst the evolving landscape of this disease with the advent of direct-acting antiviral agents (DAAs). There has been a $20 \%$ increase in organ transplants within the United States during the last 5 years that is largely attributable to an increase in available donors from drug-overdose deaths. ${ }^{2,3}$ These donors have high incidence of $\mathrm{HCV}$ infection, and, thus, ongoing strategies to improve donor use, including transplanting organs from hepatitis $\mathrm{C}$-viremic donors, are being evaluated.

Given the concern for worse graft survival and other HCV-related complications in the pre-DAA era, the transplant community has been cautious about transplanting organs from $\mathrm{HCV}$-infected donors during the past few years. ${ }^{4}$ However, now in 2019, as more and more single-center experiences show that organs can be safely and effectively transplanted from HCV-infected donors into uninfected recipients, it is time to sideline the debate of whether this should be done and, rather, focus the discussion on how best to implement this strategy so it can be adopted by all transplant centers in the most effective and safest way., Competing risks of using extended-criteria organs must be balanced with the risk and increased mortality associated with not receiving a transplant. Robust data have demonstrated that patients declining donor lungs from increased-

From the ${ }^{\mathrm{a} D i v i s i o n}$ of Thoracic Surgery, University of Toronto and ${ }^{\mathrm{b}}$ University Health Network Transplant Program, Toronto Lung Transplant Program, Toronto, Canada; and 'Department of Infectious Diseases, Brigham and Women's Hospital, Boston, Mass.

Disclosures: Authors have nothing to disclose with regard to commercial support.

Received for publication Nov 7, 2019; revisions received Nov 7, 2019; accepted for publication Nov 7, 2019; available ahead of print Jan 24, 2020.

Address for reprints: Marcelo Cypel, MSc, MD, Department of Surgery, University of Toronto, 200 Elizabeth St, 9N969, Toronto, Ontario M5G 2C4, Canada (E-mail: marcelo.cypel@uhn.ca).

J Thorac Cardiovasc Surg 2020;159:2126-7

$0022-5223 / \$ 36.00$

Copyright $\Subset 2019$ Published by Elsevier Inc. on behalf of The American Association for Thoracic Surgery

https://doi.org/10.1016/j.jtcvs.2019.11.015

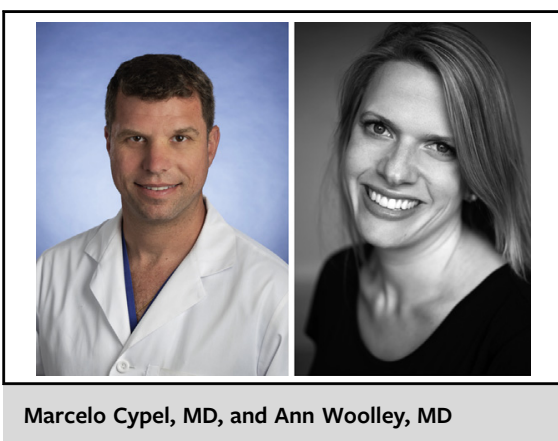

CENTRAL MESSAGE

Use of hepatitis C viremic donors

can significantly increase the

donor pool and should be

routinely offered to consented

recipients. Several studies have

now demonstrated the safety of

this approach.

risk donors have a significant increase in mortality on the wait list. ${ }^{7}$

Medically suitable organs from $\mathrm{HCV}$-infected donors continue to be declined. This in part is due to the associated stigma surrounding HCV as well as the high cost of DAA regimens and lack of long-term follow-up data in this area. Other donor risk factors, such as cytomegalovirus (CMV) seropositivity or smoking history, have a much greater adverse clinical impact to transplant recipients; however, these increased risk factors do not warrant a separate pretransplant consent process and rarely do transplant professionals advise recipients about these additional donor risk factors. CMV mismatch confers a marked risk of CMV disease and graft dysfunction after transplantation, ${ }^{8}$ and use of a smoker's lungs with $>20$ pack/years leads to decreased 5-year survival. ${ }^{9}$ In contrast, studies have demonstrated near $100 \%$ cure rate with the use of DAAs post-HCV transplants, and even the few reported failures have been successfully retreated. ${ }^{5,6}$ In all reports within the previous 3 years, short-term post-transplant survival and graft function rates have been the same compared with recipients receiving noninfected organs. The challenges of using DAA in the early post-transplant period described by Raemdonck and colleagues their report are theoretical concerns that have not been born out in clinical studies. For example, there are multiple pan-genotypic regimens that can be safely used in patients with renal dysfunction. Data showing the efficacy of crushing DAAs and administering them via 
feeding tubes are emerging. Some recent studies have indicated that much shorter duration of DAAs can be used, hence greatly decreasing costs.

In summary, we believe organs from HCV viremic donors should be assessed and considered for transplantation and patients should have the opportunity to receive these life-saving organ transplants after informed consent. Future research is ongoing to help determine the best protocol to implement to block transmission or block viral replication in the recipient.

\section{References}

1. Raemdonck DV, Nevens F, Cleemput JV, Vos R, Neyrinck A, Verleden GM. Fishing in the thoracic organ donor pool: what next if the catch of the day got infected with hepatitis C virus? J Thorac Cardiovasc Surg. 2020;159: 2121-5.

2. Goldberg DS, Blumberg E, McCauley M, Abt P, Levine M. Improving organ utilization to help overcome the tragedies of the opioid epidemic. Am J Transplant. 2016;16:2836-41.
3. Mehra MR, Jarcho JA, Cherikh W, Vaduganathan M, Lehman RR, Smits J, et al. The drug-intoxication epidemic and solid-organ transplantation. $N$ Engl J Med. 2018;378:1943-5.

4. Englum BR, Ganapathi AM, Speicher PJ, Gulack BC, Snyder LD, Duane Davis R, et al. Impact of donor and recipient hepatitis $\mathrm{C}$ status in lung transplantation. $J$ Heart Lung Transplant. 2016;35:228-35.

5. Woolley AE, Singh SK, Goldberg HJ, Mallidi HR, Givertz MM, Mehra MR, et al. Heart and lung transplants from HCV-infected donors to uninfected recipients. $N$ Engl J Med. 2019;380:1606-17.

6. Cypel M, Feld JJ, Galasso M, Pinto Ribeiro RV, Marks N, Kuczynski M, et al Prevention of viral transmission during lung transplantation with hepatitis C-viraemic donors: an open-label, single-centre, pilot trial. Lancet Respir Med. 2020;8:192-201.

7. Cox ML, Mulvihill MS, Choi AY, Bishawi M, Osho AA, Haney JC, et al. Implications of declining donor offers with increased risk of disease transmission on waiting list survival in lung transplantation. J Heart Lung Transplant. 2019;38: 295-305.

8. Beam E, Lesnick T, Kremers W, Kennedy CC, Razonable RR. Cytomegalovirus disease is associated with higher all-cause mortality after lung transplantation despite extended antiviral prophylaxis. Clin Transplant. 2016;30:270-8.

9. Bonser RS, Taylor R, Collett D, Thomas HL, Dark JH, Neuberger J. Effect of donor smoking on survival after lung transplantation: a cohort study of a prospective registry. Lancet. 2012;380:747-55. 